\title{
OPTIMASI PROSES SPRAY DRYING PADA ENKAPSULASI ANTOSIANIN UBI UNGU
}

\author{
Retno Yunilawati, Yemirta, Agustina Arianita C., Silvie Ardhanie A., Nur Hidayati, \\ dan Dwinna Rahmi \\ Balai Besar Kimia dan Kemasan, Kementerian Perindustrian \\ Jl. Balai Kimia I Pekayon, Pasar Rebo, Jakarta Timur \\ E-mail : retnoyunilawati@gmail.com
}

Received: 19 Maret 2018; revised: 19 Maret 2018; accepted: 11 April 2018

\begin{abstract}
ABSTRAK
OPTIMASI PROSES SPRAY DRYING PADA ENKAPSULASI ANTOSIANIN UBI UNGU. Teknologi proses spray drying banyak dilakukan pada enkapsulasi zat warna alam untuk aplikasi di industri. Pada penelitian ini dilakukan enkapsulasi antosianin ubi ungu dengan teknik spray drying. Tujuan dari penelitian ini adalah optimasi proses spray drying pada enkapsulasi antosianin ubi ungu. Optimasi proses dilakukan pada kondisi berbagai suhu inlet $\left(150^{\circ} \mathrm{C}\right.$ sampai dengan $180^{\circ} \mathrm{C}$ ) dan jumlah maltodekstrin sebagai carrier (5\% sampai dengan $\left.15 \%\right)$. Sebagai respon dilakukan pengukuran kadar air, absorbansi, dan kadar antosianin. Response Surface Methodology (RSM) dengan metode Central Composite Design (CCD) digunakan untuk analisis data optimasi. Hasil analisis menunjukkan bahwa suhu inlet dan persentase maltodekstrin berpengaruh secara signifikan terhadap kadar air, absorbansi, dan kadar antosianin total. Kondisi optimal didapatkan pada suhu inlet $166,96{ }^{\circ} \mathrm{C}$ dan maltodekstrin sebesar 5\%. Pada kondisi ini dihasilkan serbuk antosianin ubi ungu dengan kadar air 4,79\%; absorbansi 0,8827; dan kadar antosianin total 968,65 mg/kg.
\end{abstract}

Kata kunci : Spray drying, Enkapsulasi, Antosianin ubi ungu, Central Composite Design

\begin{abstract}
OPTIMIZATION OF SPRAY DRYING ON ENCAPSULATION OF PURPLE SWEET POTATO ANTHOCYANIN. Spray drying process technology is mostly done on encapsulation of natural dye for industrial applications. This paper presents an encapsulation of purple sweet potato anthocyanin with spray drying technique. The purpose of this research is to optimize spray drying process on purple sweet potato antosianin encapsulation. The optimization of the process is carried out under various inlet temperature conditions $\left(150{ }^{\circ} \mathrm{C}\right.$ to $\left.180{ }^{\circ} \mathrm{C}\right)$ and the amount of maltodextrin as carrier (5\% to 15\%). Water content, absorbance, and total anthocyanin content were measured on encapsulation products. Response Surface Methodology (RSM) using the Central Composite Design (CCD) method was used for data optimization analysis. The results showed that inlet temperature and maltodextrin percentage had significant effect on water content, absorbance, and total anthocyanin content. Optimal conditions were obtained at an inlet temperature of $166.96{ }^{\circ} \mathrm{C}$ and maltodextrin of $5 \%$. This condition resulted purple sweet potato antosianin powder with water content of $4,79 \%$, absorbance of 0,8827 and total anthocyanin content $968,65 \mathrm{mg} / \mathrm{kg}$.
\end{abstract}

Key words : Spray drying, Encapsulation, Purple sweet potato anthocyanin, Central Composite Design

\section{PENDAHULUAN}

Pewarna alam merupakan pewarna yang diperoleh dari sumber daya alam, baik tanaman, hewan, mikroba, maupun mineral. Pewarna alam sejak dahulu banyak digunakan untuk makanan dan terus berkembang hingga aplikasi pada produk kosmetika, farmasi, dan tekstil. Penggunaan pewarna alam terus meningkat sejalan dengan adanya tren "back to nature" yang mendorong penggunaan bahan-bahan yang bersifat aman dan ramah lingkungan (Aberoumand 2011).
Sama seperti bahan lainnya, pewarna alam dijumpai di alam tidak sebagai senyawa tunggal tetapi merupakan campuran dalam satu golongan. Berdasarkan konstituen kimia utama yang terdapat di dalamnya, pewarna alam digolongkan menjadi golongan indigoid, antrakuinon, naftokuinon dan benzokuinon, flavonoid, karotenoid, dan tanin. Salah satu pewarna golongan flavonoid adalah antosianin yang banyak ditemukan pada bunga, buah, daun, batang, dan akar dari tanaman (Silva et al. 
2013) yang menghasilkan warna merah, biru, atau ungu. Antosianin banyak digunakan sebagai pewarna makanan terutama pada minuman ringan, permen, es krim, yoghurt, dan serbuk minuman (Mahdavi et al. 2014). Beberapa tanaman penghasil pewarna alam antosianin ini antara lain strawberry, blueberry, rosela, anggur, lobak merak, plum, duwet (jamblang), dan ubi ungu.

Penggunaan antosianin sebagai pewarna alam selain memberikan warna yang indah pada produk yang diwarnainya, juga karena adanya pengaruh baik bagi kesehatan, yaitu sebagai antioksidan alami. Disamping dari keunggulannya tersebut, zat warna antosianin memiliki masalah dalam penggunaannya, yaitu ketidakstabilannya dan mudah terdegradasi selama penyimpanan(Mahdavi et al. 2014). Permasalahan ini dapat diatasi dengan teknik enkapsulasi, seperti yang pernah dilakukan pada pewarna alam dari buah naga (Woo et al. 2011), barberry (Mahdavi et al. 2016), dan pitaya (Chik et al. 2011).

Enkapsulasi adalah suatu teknik untuk melapisi atau menyalut suatu bahan aktif dengan lapisan dinding polimer sehingga menghasilkan partikel kecil berukuran mikro ataupun nano. Pelapisan atau penyalutan ini dapat melindungi bahan aktif dari kondisi lingkungan sekitar seperti cahaya, suhu, kelembaban, dan dari interaksi dengan zat lainnya. Ada beberapa teknik yang sering digunakan enkapsulasi pewarna alam, seperti spray drying, freeze drying, coaservation, dan emulsi. Diantara semua teknik tersebut, spray drying yang paling banyak digunakan (Özkan dan Bilek 2014).

Pada penelitian ini dilakukan enkapsulasi antosianin dari ubi ungu menggunakan teknik spray drying. Antosianin terdapat dalam jumlah yang cukup besar pada ubi ungu yaitu sekitar $24,6 \mathrm{mg} / 100 \mathrm{~g}$ sampai dengan $45,1 \mathrm{mg} / 100 \mathrm{~g}$ berat segar ubi ungu (Montilla, Hillebrand, dan Winterhalter 2011). Enkapsulasi dengan spray drying bertujuan untuk dapat mengatasi ketidakstabilan antosianin ubi ungu terutama selama penyimpanan. Teknik spray drying akan menghasilkan serbuk antosianin dengan sifat fisiko kimia yang bergantung pada variabel operasinya seperti suhu inlet udara pengering, laju alir udara pengering, laju suplai umpan cairan/ sampel, dan tekanan/volum udara atomisasi. Parameter tersebut harus dikontrol agar dapat menghasilkan serbuk dengan kadar antosianin dan intensitas warna yang tinggi namun kadar air tetap rendah.

Tujuan dari penelitian ini adalah optimasi kondisi proses spray drying pada enkapsulasi antosianin ubi ungu. Optimasi kondisi spray dryer pada enkapsulasi antosianin ubi ungu dilakukan dengan metode Response Surface
Methodology (RSM) berdasarkan perancangan menggunakan Central Composite Design (CCD). $R S M$ adalah suatu metode statistika dan matematika dalam merancang percobaan untuk mengevaluasi pengaruh beberapa variabel dan menentukan kondisi optimal dari respon yang diinginkan (Keharom, Mahachai, dan Chanthai 2016). CCD merupakan salah satu dari metode $R S M$ yang menggunakan statistik sebagai dasar perhitungannya sehingga dapat dihasilkan data yang dipercaya tanpa membutuhkan banyak percobaan. Optimasi proses spray drying pada enkapsulasi antosianin ubi ungu ini dapat membantu dalam pengaplikasian pewarna alam dari ubi ungu dalam industri seperti industri makanan dan obat-obatan.

\section{BAHAN DAN METODE}

\section{Bahan}

Bahan-bahan yang digunakan dalam penelitian ini antara lain ubi ungu (Ipomoea batatas), air, asam sitrat (food grade), larutan buffer $\mathrm{pH} \mathrm{1}$, dan larutan buffer $\mathrm{pH} 4,5$. Peralatan yang digunakan terdiri dari penangas air (water bath), sentrifusa, rotary evaporator, oven vakum, spektrofotometer Pharo 300 Spectroquant, dan Buchi mini spray dryer B-290.

\section{Metode \\ Penyiapan Ekstrak Antosianin Ubi Ungu}

Ubi ungu dicuci bersih, dikeringkan pada suhu ruang, kemudian dipotong-potong kecil, ditambahkan air dengan perbandingan jumlah ubi ungu dan air (1:2), kemudain diblansir (rebus) pada suhu $70^{\circ} \mathrm{C}$ selama 10 menit, dan disaring. Filtrat ditambahkan asam sitrat (food grade) hingga $\mathrm{pH} 2$. Setelah tercapai $\mathrm{pH} 2$, filtrat dicampurkan dengan ampas dan diblender sebentar, kemudian dipanaskan pada suhu $90{ }^{\circ} \mathrm{C}$. Setelah itu disaring kembali, diambil filtratnya, dan disentrifus untuk mengendapkan karbohidratnya. Filtrat kemudian dipekatkan menggunakan rotary evaporator hingga didapatkan volume filtrat sebesar setengah dari volume awal filtrat. Filtrat yang didapatkan ini merupakan ekstrak pekat antosianin ubi ungu.

\section{Enkapsulasi Antosianin Ubi Ungu}

Enkapsulasi antosianin ubi ungu dilakukan menggunakan spray dryer merk Buchi mini spray dryer B-290. Suhu inlet dan jumlah filler (maltodekstrin) dijadikan sebagai variabel berubah. Suhu inlet bervariasi dari $150{ }^{\circ} \mathrm{C}$ sampai $180 \quad{ }^{\circ} \mathrm{C}$ (Tabel 1), dan jumlah maltodekstrin bervariasi dari $5 \%$ hingga $15 \%$. Setelah proses mikroenkapsulasi selesai, serbuk dimasukkan dalam wadah polietilen dan dilakukan analisis lebih lanjut yang meliputi kadar air, intensitas warna, dan kadar antosianin total. 
Tabel 1. Parameter berubah pada proses optimasi

\begin{tabular}{lccc}
\hline \multicolumn{1}{c}{ Parameter berubah } & Nilai bawah & Nilai tengah & Nilai atas \\
\hline $\mathrm{A}:$ T inlet $\left({ }^{\circ} \mathrm{C}\right)$ & 150 & 165.5 & 180 \\
$\mathrm{~B}:$ Maltodekstrin $(\%)$ & 5 & 10 & 15 \\
\hline
\end{tabular}

Percobaan optimasi dirancang dengan Central Composite Design (CCD) yang merupakan salah satu metode Response Surface Methodology (RSM),seperti pada Tabel 2.

Tabel 2. Rancangan percobaan optimasi

\begin{tabular}{lll}
\hline Run & T inlet $\left({ }^{\circ} \mathrm{C}\right)$ & Maltodekstrin $(\%)$ \\
\hline 1 & 165.00 & 10.00 \\
2 & 180.00 & 5.00 \\
3 & 165.00 & 10.00 \\
4 & 150.00 & 15.00 \\
5 & 180.00 & 15.00 \\
6 & 165.00 & 10.00 \\
7 & 150.00 & 5.00 \\
8 & 143.79 & 10.00 \\
9 & 165.00 & 10.00 \\
10 & 186.21 & 10.00 \\
11 & 165.00 & 17.07 \\
12 & 165.00 & 2.93 \\
13 & 165.00 & 10.00 \\
14 & 165.00 & 10.00 \\
\hline
\end{tabular}

Analisis Kadar Air (Muzaffar, Dinkarrao, dan Kumar 2016)

Serbuk antosianin ubi ungu ditimbang sebanyak $2 \mathrm{~g}$, dikeringkan dalam oven vakum bersuhu $70^{\circ} \mathrm{C}$ hingga diperoleh berat tetap (lama pengeringan sekitar 2 jam).

Analisis Kadar Antosianin Total (Ferrari, Germer, dan de Aguirre 2012)

Kadar antosianin total ditentukan berdasarkan perbedaan absorbansi larutan contoh pada $\mathrm{pH}$ yang berbeda. Serbuk antosianin ditimbang kemudian dilarutkan dalam larutan buffer $\mathrm{pH} 1,0$ dan larutan buffer $\mathrm{pH} 4,5$. Konsentrasi antosianin dalam larutan buffer dibuat sedemikian rupa sehingga menghasilkan absorban sekitar 0,2. Larutan diukur absorbansinya menggunakan spektrofotometer UV-vis pada panjang gelombang $520 \mathrm{~nm}$ dan $700 \mathrm{~nm}$.

Hitung absorbansi terkoreksi dengan rumus : $A=\left(A_{520 \mathrm{~nm}}-A_{700 \mathrm{~nm}}\right) p H 1-\left(A_{520 \mathrm{~nm}}-A_{700 \mathrm{~nm}}\right) p H 4,5$
Kadar antosianin total dihitung sebagai ekivalen cyanidin-3glukosida dengan rumus :

$\frac{\mathrm{A} \times \mathrm{MW} \times \mathrm{DF} \times 10000}{\varepsilon \times l}$

A = absorbansi terkoreksi

MW = berat molekul $(449,2 \mathrm{~g} / \mathrm{mol})$

$\mathrm{DF}=$ dillution factor (faktor pengenceran)

$\varepsilon=$ molar extinction coefficient (26900)

I = lebar celah kuvet $(1 \mathrm{~cm})$

\section{Analisis Intensitas Warna}

Serbuk antosianin ubi ungu dilarutkan dalam air dengan konsentrasi $1 \%$ (berat/volume), kemudian diukur absorbansinya pada panjang gelombang maksimum antosianin ubi ungu menggunakan spectroquant.

\section{Analisis Statistika}

Data hasil optimasi metode $C C D$ kemudian diolah dengan menggunakan software Design Expert巴 (versi 6.0).

\section{HASIL DAN PEMBAHASAN}

\section{Ekstrak Antosianin Ubi Ungu}

Ekstrak antosianin ubi ungu yang dihasilkan berwarna merah keunguan. Analisis menggunakan spektrofotometer uv-vis menunjukkan absorbansi optimum pada panjang gelombang $530 \mathrm{~nm}$ (Gambar 1) seperti pada beberapa penelitian sebelumnya ( $\mathrm{He}$ et al. 2015); (Montilla, Hillebrand, dan Winterhalter 2011). Panjang gelombang ini nantinya akan digunakan dalam analisis intensitas warna serbuk antosianin hasil mikroenkapsulasi.

Ekstrak antosianin yang telah dipekatkan mengandung kadar antosianin total sebesar 1700 mg/L (dihitung sebagai sianidin glukosida).

\section{Enkapsulasi Ekstrak Antosianin Ubi Ungu}

Enkapsulasi merupakan teknologi yang berkembang dengan pesat untuk mengemas bahan aktif dalam bentuk partikel berukuran mikro atau nano (Mahdavi et al. 2014). Enkapsulasi didefinisikan sebagai proses untuk memasukkan zat aktif ke dalam suatu bahan berupa dinding. Tujuan utama dari enkapsulasi ini adalah untuk melindungi bahan aktif dari kondisi lingkungan yang buruk seperti pengaruh cahaya, kelembaban dan oksigen yang tidak diinginkan sehingga berkontribusi terhadap umur simpan produk (Ersus dan Yurdagel 2007) 
Beberapa teknik enkapsulasi dapat dipilih untuk diterapkan pada zat warna antosianin, tergantung pada aplikasi spesifik, ukuran partikel yang dibutuhkan, sifat fisika kimia dari bahan aktif dan pelapis, serta biaya yang diperlukan. Enkapsulasi dengan proses spray dryer paling umum dilakukan karena biaya proses murah, proses pengeringan yang cepat, menghasilkan partikel kering yang berkualitas baik, dan mudah untuk scale-up. Enkapsulasi dengan spray drying ini telah berhasil diterapkan untuk beberapa zat warna antosianin (Sharifi et al. 2015); (Robert dan Fredes 2015);(Borges et al. 2016).

Pada proses enkapsulasi, diperlukan enkapsulan yang berfungsi sebagai dinding untuk melapisi bahan aktif. Enkapsulan harus bersifat mampu membentuk film, mudah terurai secara alami, memiliki viskositas yang rendah dan higroskopisitas rendah. Enkapsulan ini dapat berupa polisakarida (pati, maltodekstrin, sirup jagung, gum Arabic), lipid (asam stearat, monogliserida dan digliserida), dan protein (kasein, gelatin, susu kedelai, dan gandum). Penggunaan enkapsulan tergantung pada karakteristik fisika kimia partikel yang diinginkan dan juga karakteristik bahan aktif. Antosianin adalah zat warna yang larut dalam air yang akan kompatibel dengan enkapsulan berbasis air, seperti maltodekstrin, sehingga dalam penelitian ini digunakan maltodekstrin sebagai enkapsulan dari antosianin ubi ungu.

Enkapsulasi antosianin ubi ungu pada berbagai kondisi suhu inlet spray dryer dan jumlah maltodekstrin menghasilkan serbuk dengan warna yang berbeda-beda seperti diperlihatkan pada Gambar 2.

Hasil pengukuran kadar air, absorbansi, dan kadar antosianin total untuk masing-masing percobaan tercantum dalam Tabel 3. Untuk mengevaluasi signifikansi dari masing-masing faktor ( $T$ inlet dan persentase maltodekstrin) terhadap respon (kadar air, absorbansi, kadar antosianin total) dilakukan analisis statistik ANOVA. Hasil ANOVA menunjukkan bahwa model kuadratik polinomial adalah model yang cocok untuk mewakili data percobaan. Data ANOVA untuk setiap variabel respon dan signifikansinya pada tingkat kepercayaan 95\% dan koefisien korelasinya ditunjukkan pada Tabel 4. Suhu inlet dan persentase maltodekstrin berpengaruh secara signifikan terhadap kadar air.

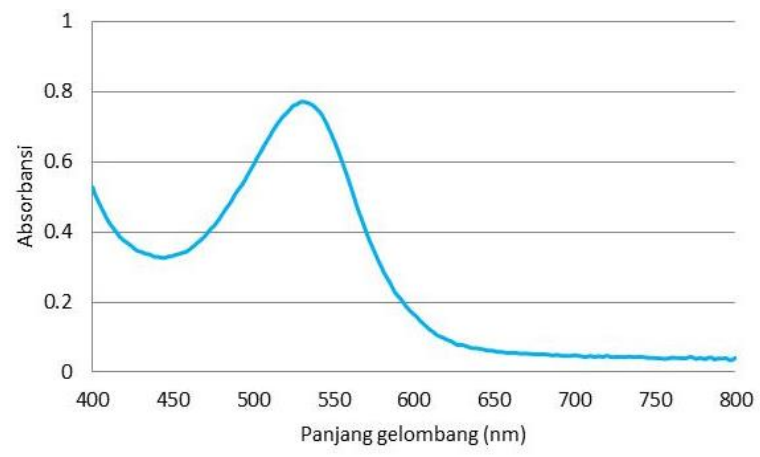

Gambar 1. Spektrum sinar tampak dari ekstrak antosianin ubi ungu

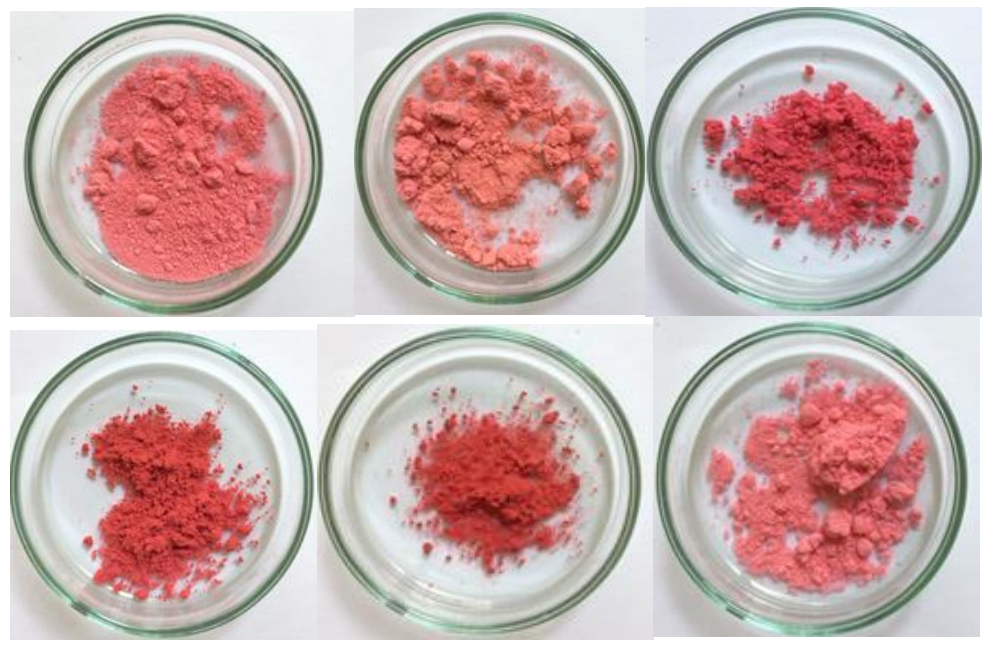

Gambar 2. Serbuk antosianin ubi ungu hasil spray drying pada berbagai kondisi 
Tabel 3. Respon percobaan (kadar air, absorbansi dan kadar antosianin total) berdasarkan faktor (T inlet dan persentase maltodekstrin)

\begin{tabular}{|c|c|c|c|c|c|}
\hline \multirow[t]{2}{*}{ Run } & \multicolumn{2}{|l|}{ Faktor } & \multicolumn{3}{|l|}{ Respon } \\
\hline & $\begin{array}{l}\text { A } \\
\left(\text { T Inlet, }{ }^{\circ} \mathrm{C}\right)\end{array}$ & $\begin{array}{l}\text { B } \\
\text { (\%malto) }\end{array}$ & $\begin{array}{l}\mathrm{y}_{1} \\
\text { (Kadar air, \%) }\end{array}$ & $\begin{array}{l}\mathrm{y}_{2} \\
\text { (Absorbansi) }\end{array}$ & $\begin{array}{l}\mathrm{y}_{3} \\
\text { (Antosianin total } ; \mathrm{mg} / \mathrm{kg})\end{array}$ \\
\hline 1 & 165.00 & 10.00 & 3.49 & 0.623 & 645.4 \\
\hline 2 & 180.00 & 5.00 & 5.27 & 0.629 & 659.4 \\
\hline 3 & 165.00 & 10.00 & 3.49 & 0.623 & 645.4 \\
\hline 4 & 150.00 & 15.00 & 5.09 & 0.46 & 530.18 \\
\hline 5 & 180.00 & 15.00 & 5.99 & 0.411 & 328.17 \\
\hline 6 & 165.00 & 10.00 & 3.49 & 0.623 & 645.4 \\
\hline 7 & 150.00 & 5.00 & 8.58 & 0.804 & 879.05 \\
\hline 8 & 143.79 & 10.00 & 8.09 & 0.503 & 534.84 \\
\hline 9 & 165.00 & 10.00 & 3.49 & 0.623 & 645.4 \\
\hline 10 & 186.21 & 10.00 & 5.34 & 0.424 & 388.94 \\
\hline 11 & 165.00 & 17.07 & 5.15 & 0.371 & 285.31 \\
\hline 12 & 165.00 & 2.93 & 5.86 & 1.182 & 1313.09 \\
\hline 13 & 165.00 & 10.00 & 3.49 & 0.623 & 645.4 \\
\hline 14 & 165.00 & 10.00 & 3.49 & 0.623 & 645.4 \\
\hline
\end{tabular}

Tabel 4. Tingkat signifikan ANOVA model kuadratik polinomial untuk respon kadar air, absorbansi, dan kadar antosianin

\begin{tabular}{llll} 
& & & \\
\hline $\mathrm{P}>\mathrm{F}$ & Kadar air $(\%)$ & Absorbansi & Antosianin total $(\mathrm{mg} / \mathrm{kg})$ \\
\hline Model & $<0,0001^{*}$ & $0,0017^{*}$ & $0,0021^{*}$ \\
$\mathrm{~A}$ (T inlet) & $0,0002^{*}$ & 0,0773 & 0,0785 \\
$\mathrm{~B}(\%$ maltodekstrin) & $0,0036^{*}$ & $0,0002^{*}$ & $0,0002^{*}$ \\
$\mathrm{~A}^{2}$ & $<0,0001^{*}$ & $0,0500^{*}$ & $0,0404^{*}$ \\
$\mathrm{~B}^{2}$ & $<0,0001^{*}$ & 0,0891 & 0,1253 \\
$\mathrm{AB}$ & $0,0003^{*}$ & 0,4866 & 0,9371 \\
\hline $\mathrm{R}^{2}$ & 0,9822 & 0,9074 & 0,9003 \\
\hline
\end{tabular}

${ }^{*}$ signifikan

\section{Kadar Air Serbuk Enkapsulasi}

Hasil pengukuran kadar air terhadap produk enkapsulasi selengkapnya telah disajikan pada Tabel 3. Persamaan model regresi untuk kadar air berdasarkan analisis ANOVA adalah :

$\begin{aligned} \text { Kadar air }\left(y_{1}\right)= & 3,49-0,79 A-0,47 B+ \\ & 1,64 A^{2}+1,04 B^{2}+1,05 A B . .(3)\end{aligned}$

Persamaan (3) menunjukkan kenaikan suhu inlet dan kenaikan persentase maltodekstrin menyebabkan penurunan kadar air. Hal ini dapat dilihat lebih jelas melalui gambar respon tiga dimensi pada Gambar 3 . Suhu inlet yang tinggi menyebabkan gradien suhu yang besar antara umpan yang diatomisasi dan udara pengeringan yang menghasilkan energi pendorong penguapan air lebih besar sehingga menghasilkan serbuk yang lebih kering (Muzaffar, Dinkarrao, dan Kumar 2016). Kadar air yang rendah dapat memperpanjang umur simpan dari antosianin, karena akan memperlambat pertumbuhan jamur sehingga tidak merusak sifat dari antosianin.

\section{Intensitas Warna/ Absorbansi Serbuk Enkapsulasi}

Intensitas zat warna dari masing-masing serbuk enkapsulasi dapat diketahui dengan melakukan analisa absorbansi menggunakan spektrofotometer pada panjang gelombang maksimum yang telah ditentukan sebelumnya $(530 \mathrm{~nm})$. Absorbansi turun dengan semakin banyaknya jumlah maltodekstrin, dan semakin besar dengan adanya kenaikan suhu inlet namun pada suhu inlet lebih dari $167{ }^{\circ} \mathrm{C}$ absorbansi menjadi turun (Gambar 4). Sebagaimana hukum Lambert Beer yang menyatakan bahwa jumlah radiasi cahaya tampak, ultraviolet, dan cahaya-cahaya lain yang diserap atau ditransmisikan oleh suatu larutan merupakan fungsi eksponensial dari konsentrasi zat dan tebal larutan, maka absorbansi yang besar berarti konsentrasi zat warna antosianinnya juga besar. Adanya penurunan absorbansi pada suhu inlet di atas $167{ }^{\circ} \mathrm{C}$ disebabkan karena ketidakstabilan antosianin pada suhu tinggi sehingga terjadi degradasi. 


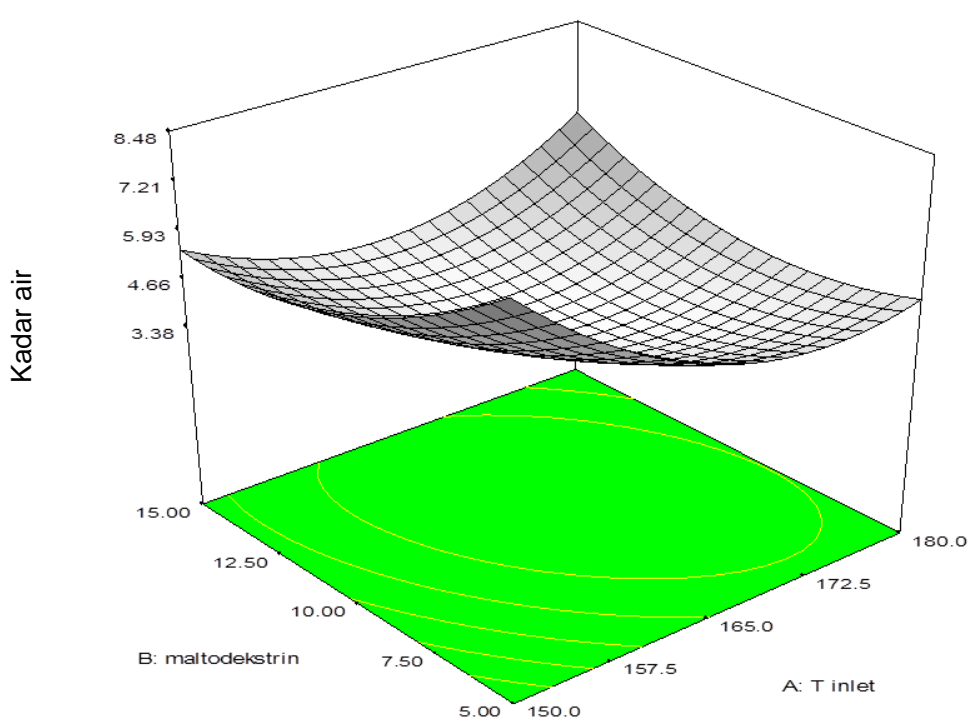

Gambar 3. Respon permukaan 3 dimensi dari pengaruh suhu inlet dan jumlah maltodekstrin terhadap kadar air

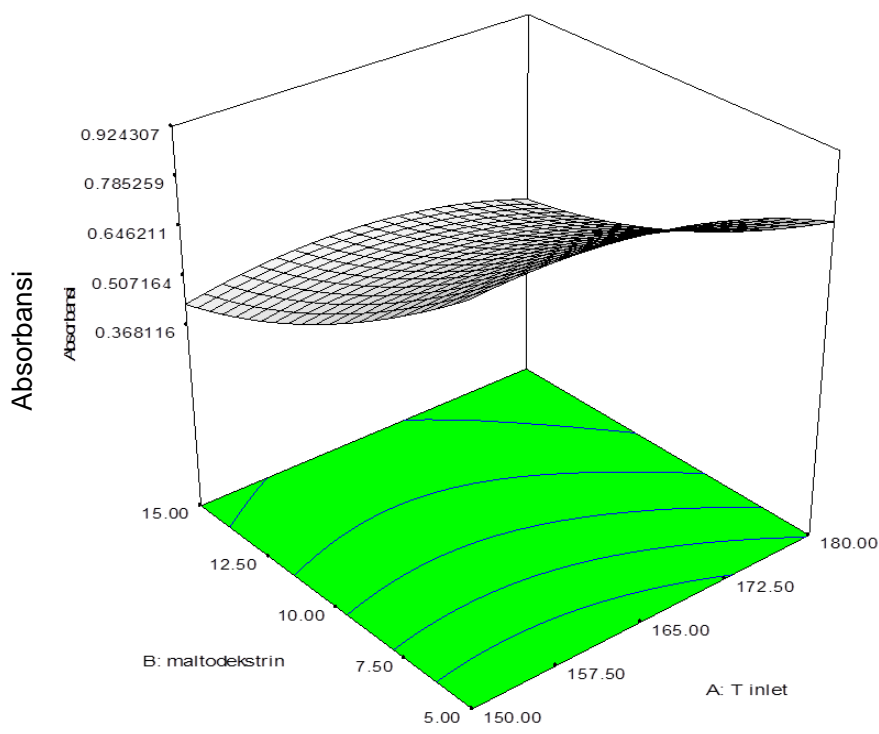

Gambar 4. Respon permukaan 3 dimensi dari pengaruh suhu inlet dan jumlah maltodekstrin terhadap absorbansi

\section{Kadar Antosianin Total Serbuk Enkapsulasi}

Kenaikan suhu inlet hingga suhu tertentu

$\left(167{ }^{\circ} \mathrm{C}\right)$ menyebabkan kadar antosianin total meningkat. Suhu inlet yang lebih dari $167^{\circ} \mathrm{C}$ menyebabkan kadar antosianin total menjadi turun (Gambar 5). Hal ini disebabkan karena sifat dari antosianin yang tidak stabil pada suhu tinggi sehingga mudah terdegradasi seperti pada beberapa penelitian (Muzaffar, Dinkarrao, dan Kumar 2016) (Sharifi et al. 2015). Degradasi antosianin pada suhu tinggi juga terkait adanya gugus gula dan protein yang dapat menyebabkan terjadinya reaksi Maillard pada suhu tinggi. Reaksi Maillard menghasilkan hidroksimetilfurfural berwarna coklat yang ikut mengembun bersama serbuk antosianin. Pada suhu inlet spray dryer yang sangat tinggi, dihasilkan serbuk antosianin yang berwarna coklat akibat adanya senyawa hidroksimetilfurfural ini.

\section{Optimasi Proses Spray Drying}

Optimasi proses spray drying ini ditujukan untuk mendapatkan serbuk antosianin ubi ungu dengan kadar air rendah, absorbansi tinggi dan kadar antosianin yang tinggi dari parameter suhu inlet dan persentase maltodekstrin. Analisis menggunakan CCD menghasilkan data untuk optimasi seperti pada Tabel 5. Berdasarkan data tersebut, proses spray drying berlangsung optimal pada suhu inlet $166,96{ }^{\circ} \mathrm{C}$ dan persentase maltodekstrin sebesar $5 \%$ yang akan menghasilkan serbuk antosianin ubi ungu dengan kadar air 4,79\%, absorbansi 0,8827 dan kadar antosianin total $968,65 \mathrm{mg} / \mathrm{kg}$. 


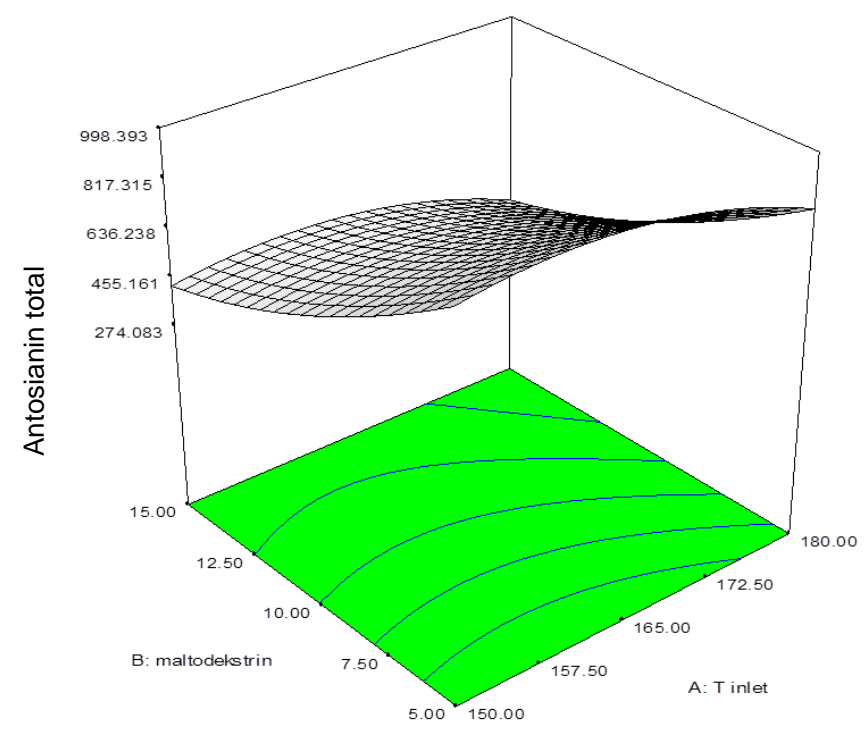

Gambar 5. Respon permukaan 3 dimensi dari pengaruh suhu inlet dan jumlah maltodekstrin terhadap kadar antosianin total

Tabel 5. Data hasil optimasi spray drying yang dianalisis menggunakan $C C D$

\begin{tabular}{|c|c|c|c|c|c|c|c|}
\hline & & Lower & Upper & Lower & Upper & & \\
\hline Name & Goal & Limit & Limit & Weight & Weight & Importance & \\
\hline$T$ inlet & is in range & 150 & 180 & 1 & 1 & 3 & \\
\hline maltodekstrin & minimize & 5 & 15 & 1 & 1 & 3 & \\
\hline Kadar air & minimize & 3.49 & 8.58 & 1 & 1 & 3 & \\
\hline Antosianin total & maximize & 285.31 & 1313.09 & 1 & 1 & 3 & \\
\hline Absorbansi & maximize & 0.371 & 1.182 & 1 & 1 & 3 & \\
\hline \multicolumn{8}{|l|}{ Solutions } \\
\hline Number & $T$ inlet & maltodekstrin & Kadar air & Antosianin total & Absorbansi & Desirability & \\
\hline 1 & $\underline{168.98}$ & $\underline{5.00}$ & $\underline{4.79}$ & $\underline{988.653}$ & $\underline{0.882775}$ & $\underline{0.748}$ & Selected \\
\hline 2 & 168.06 & 5.00 & 4.88 & 974.795 & 0.889038 & 0.747 & \\
\hline
\end{tabular}

\section{KESIMPULAN}

Proses spray drying pada enkapsulasi antosianin ubi ungu dipengaruhi oleh suhu inlet dan persentase maltodekstrin. Optimasi proses spray drying enkapsulasi antosianin ubi ungu menggunakan RSM dengan metode $C C D$ menghasilkan kondisi terbaik pada suhu inlet $166,96{ }^{\circ} \mathrm{C}$ dan maltodekstrin $5 \%$. Data ini dapat digunakan untuk menyiapkan serbuk antosianin ubi ungu secara komersial menggunakan teknologi spray drying.

\section{DAFTAR PUSTAKA}

Aberoumand, A. 2011. "A Review Article on Edible Pigments Properties and Sources as Natural Biocolorants in Foodstuff and Food Industry." World Journal of Dairy \& Food Sciences 6 (1): 71-78.

Borges, K.C., M.D.F. Bezerra, M.P. Rocha, E.S.D. Silva, M.I. Fujita, A.Genovese, dan
R.T. Pinto Correia. 2016. "Fresh and Spray Dried Pitanga (Eugenia uniflora) and Jambolan (Syzygium cumini) Pulps are Natural Sources of Bioactive Compounds with Functional Attributes." Journal of Probiotics \& Health 4 (2). doi:10.4172/2329-8901.1000145.

Chik, C.T., A. Abdullah, N. Abdullah, W. Aida, dan W. Mustapha. 2011. "The Effect of Maltodextrin and Additive Added Towards Pitaya Juice Powder Total Phenolic Content and Antioxidant Activity." In International Conference on Food Engineering and Biotechnology, 9:224-28.

Ersus, S., dan U. Yurdagel. 2007. "Microencapsulation of anthocyanin pigments of black carrot (Daucus carota L.) by spray drier." Journal of Food Engineering $80 \quad$ (3): $805-12$. doi:10.1016/j.jfoodeng.2006.07.009.

Ferrari, C.C., S.P.M. Germer, dan J.M. de Aguirre. 2012. "Effects of Spray-Drying 
Conditions on the Physicochemical Properties of Blackberry Powder." Drying Technology $30 \quad$ (2): $154-63$. doi:10.1080/07373937.2011.628429.

He, Xiu-li, Xue-li Li, Yuan-ping Lv, dan Qiang He. 2015. "Composition and color stability of anthocyanin-based extract from purple sweet potato." Food Science and $\begin{array}{llll}\text { Technology } & 35 & \text { (3): } 468-73 .\end{array}$ doi:10.1590/1678-457X.6687.

Keharom, S., R. Mahachai, dan S. Chanthai. 2016. "The optimization study of $\alpha$-amylase activity based on central composite designresponse surface methodology by dinitrosalicylic acid method." International Food Research Journal 23 (1): 10-17.

Mahdavi, S.A., E. Assadpoor, S.M. Jafari, dan D. Dehnad. 2016. "Microencapsulation optimization of natural anthocyanins with maltodextrin, gum Arabic and gelatin." International Journal of Biological Macromolecules 85: 379-85. doi:10.1016/j.jjbiomac.2016.01.011.

Mahdavi, S.A., M. Ghorbani, S.M. Jafari, dan E. Assadpoor. $2014 . \quad$ "Spray-Drying Microencapsulation of Anthocyanins by Natural Biopolymers: A Review." Drying Technology 32 (5): 509-18.

Montilla, E.C., S. Hillebrand, dan P. Winterhalter. 2011. "Anthocyanins in Purple Sweet Potato ( Ipomoea batatas L .) Varieties." Fruit, Vegetable and Cereal Science and Biotechnology 5 (2): 19-24.

Muzaffar, K., B.V. Dinkarrao, dan P. Kumar. 2016. "Optimization of spray drying conditions for production of quality pomegranate juice powder." Cogent Food \& Agriculture 2 (1): 1-9. doi:10.1080/23311932.2015.1127583.

Özkan, G., dan S.E. Bilek. 2014. "Microencapsulation of natural food colourants." International Journal of Nutrition and Food Sciences 3 (3): 145-56. doi:10.11648/j.ijnfs.20140303.13.

Robert, P., dan C. Fredes. 2015. "The encapsulation of anthocyanins from berrytype fruits. Trends in foods." Molecules 20 (4): 5875-88. doi:10.3390/molecules20045875.

Sharifi, A., M. Niakousari, A. Maskooki, dan S. A. Mortazavi. 2015. "Effect of spray drying conditions on the physicochemical properties of barberry (Berberis vulgaris) extract powder." International Food Research Journal 22 (6): 2364-70.

Silva, P.I., P.C. Stringheta, R.F. Teofilo, dan I.R.N. De Oliveira. 2013. "Parameter optimization for spray-drying microencapsulation of jaboticaba (Myrciaria jaboticaba) peel extracts using simultaneous analysis of responses." Journal of Food Engineering 117 (4): 53844. doi:10.1016/j.jfoodeng.2012.08.039.

Woo, K. K., F.N.F. Wong, H. S.C. Chua, dan P. Y. Tang. 2011. "Stability of the spray-dried pigment of red dragon fruit [Hylocereus polyrhizus (Weber) Britton and rose] as a function of organic acid additives and storage conditions." Philippine Agricultural Scientist 94 (3): 264-69. 